\title{
Electrochemical Determination of Oncocalyxone A using an Iron-phthalocyanine/Iron-porphyrin Modified Glassy Carbon Electrode
}

\author{
Cicero de O. Costa, ${ }^{a}$ Antonio A. de Souza, ${ }^{a}$ Rita de Cássia S. Luz, ${ }^{b}$ Telma L. G. Lemos, ${ }^{c}$ \\ Otília D. L. Pessoa, ${ }^{c}$ Lauro T. Kubota*,b and Marília O. F. Goulart*,a \\ ${ }^{a}$ Instituto de Química e Biotecnologia, Universidade Federal de Alagoas, 57072-970 Maceió-AL, Brazil \\ ${ }^{b}$ Instituto de Química, Universidade Estadual de Campinas, 13084-862 Campinas-SP, Brazil \\ 'Departamento de Química Orgânica e Inorgânica, Universidade Federal do Ceará, 60451-970 Fortaleza-CE, Brazil
}

\begin{abstract}
Descreve-se, no presente trabalho, o desenvolvimento de um sensor voltamétrico altamente sensível para a oncocalixona A, utilizando-se eletrodo de carbono vítreo modificado com uma bicamada de ftalocianina tetrassulfonada de ferro(II) (FeTSPc) e tetra-( $N$-metil-4-piridil)-porfirina de ferro(III) (FeT $\left.\mathrm{F}_{4} \mathrm{MPyP}\right)$. O eletrodo modificado apresentou alta atividade catalítica e estabilidade em relação à redução da oncocalixona, proporcionando deslocamento anódico de $c a$. de $30 \mathrm{mV}$ e amplificação da corrente de pico, em relação a iguais parâmetros obtidos em eletrodo de carbono vítreo não modificado. Um ampla faixa linear de resposta entre $0.005-1.2 \mu \mathrm{mol} \mathrm{L}^{-1}$, com sensibilidade de $8.11 \mu \mathrm{A} \mathrm{L} \mu \mathrm{mol}^{-1}$ e limites de detecção (LOD) e quantificação (LOQ) de 1.5 e $5 \mathrm{nmol} \mathrm{L}{ }^{-1}$ foram obtidos, com o uso desse sensor.
\end{abstract}

The development of a highly sensitive voltammetric sensor for oncocalyxone A using a glassy carbon electrode modified with a bilayer iron(II) tetrasulfonated phthalocyanine (FeTSPc) and iron(III) tetra-( $N$-methyl-4-pyridyl)-porphyrin ( $\left.\mathrm{FeT}_{4} \mathrm{MPyP}\right)$ is described. The modified electrode showed high catalytic activity and stability for the oncocalyxone A reduction, provoking the anodic shift of the reduction peak potentials of $c a .30 \mathrm{mV}$ and presenting much higher peak currents than those obtained on the bare GC electrode. A wide linear response range between $0.005-1.2 \mu \mathrm{mol} \mathrm{\textrm {L } ^ { - 1 }}$, with a sensitivity of $8.11 \mu \mathrm{A} \mathrm{L} \mu \mathrm{mol}^{-1}$ and limits of detection (LOD) and quantification (LOQ) of 1.5 and $5 \mathrm{nmol} \mathrm{L}^{-1}$ were obtained with this sensor.

Keywords: voltammetric sensor, oncocalyxone, quinone, chemically modified electrodes, catalysis

\section{Introduction}

Plants are repositories for bioactive organic molecules. Several classes of natural compounds are pharmacologically active ingredients and serve as drugs and/or leads for drug developments. Among them, quinones, ubiquitous secondary metabolites, play essential roles, mainly in the biochemistry of energy production, serving as vital links in the electron transport. ${ }^{1}$ They form an important class of toxic metabolites and paradoxically, can be either, potentially carcinogenic or effective anticancer agents. The cytotoxic activity of quinones can often be correlated to their chemical behavior. The striking feature of quinone chemistry is the ease reduction and therefore their ability to act as oxidizing

\footnotetext{
*e-mail: kubota@iqm.unicamp.br; mofg@qui.ufal.br
}

or dehydrogenating agents, the driving force being the formation of a fully aromatic system..$^{2-5}$

Auxemma oncocalyx Taub. is a native Brazilian tree, characteristic of the xerophytic vegetation present in the northeastern region. It is commonly called "pau branco." The chemical investigation of A. oncocalyx heartwood extracts resulted in the isolation and characterization of several unusual terpenoid quinones and hydroquinones of $\mathrm{C}_{16}$ framework. ${ }^{6-9}$ These secondary metabolites seem to be typical of the genus and, interestingly, were isolated in a homolog series differing in their degree of oxidation, oxygenation (ether or alcohol), rearrangement and intramolecular cyclization of the terpenoid side chain. As a general pattern, all compounds possess a methoxyl group in the $\mathrm{C}-2$ position and, several of them, an angular methyl group $\beta$-oriented attached to $\mathrm{C}-8 \mathrm{a}$, besides a cis configuration for the $\mathrm{B} / \mathrm{C}$ rings. Oncocalyxone $\mathrm{A}$ (1) 
(Figure 1), rel-8 $\alpha$-Hydroxy-5-hydroxymethyl-2-methoxy8aß-methyl-7,8,8a,9-tetrahydro-1,4-anthracenedione, a deep red powder, was the first compound isolated from the EtOH extract of A. oncocalyx. This secondary metabolite, which was obtained in significant amounts $(0.13 \%$ crude extract), ${ }^{8}$ is responsible for the dark color of the heartwood of this plant.

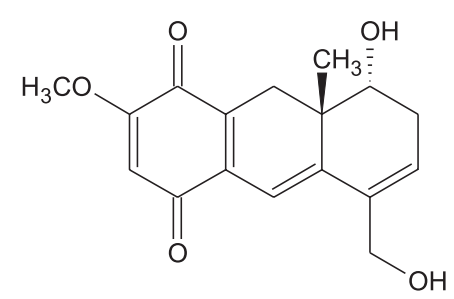

Figure 1. Chemical structure of oncocalyxone A (1).

Oncocalyxone A (1) exhibited a series of pharmacological properties, such as cytotoxic, analgesic, antiinflammatory, antioxidant and causative of inhibition of platelet activation..$^{7,10-12}$ Oncocalyxone A (1) also showed differential antitumor activity against the murine tumors Ehrlich carcinoma, sarcoma 180 and L1210 leukemia. Other pharmacological activities were also ascribed to the quinone fraction obtained from A. oncocalyx extract.

The potential pharmacological activity presented by oncocalyxone A (1) and the unusual and varied structural character of the other compounds isolated from A. oncocalyx provide important models for the synthesis of new potential biological active compounds.

Due to the importance of phytotherapy, a major impetus was generated towards improving the techniques of separation and analysis of plants of commercial importance for their standardization in terms of these recognized molecular entities. ${ }^{13-16}$

Electrochemical methods have been widely used for quantification of quinones in vegetal extracts and present the advantages of simplicity and low cost. ${ }^{17}$

The use of bare electrodes for detection of organic compounds presents a number of limitations, such as low sensitivity and reproducibility due to the slow electron transfer reaction between the electrode surface and the analyte, and lower stability. As an alternative, the use of chemically modified electrodes has been proposed, which improve the electron transfer rate, also promoting an increase in the sensitivity of the system. ${ }^{17}$ In this sense, a wide variety of compounds have been used as electron transfer mediators for electrooxidation or reduction of several target molecules. ${ }^{17-20}$

The modification of electrodes with alternating deposition of functional compounds has been attracting much interest because of its potential application, ${ }^{21-22}$ and it is a very simple way to experimentally produce complex layered structures with precise control of layer composition and thickness. ${ }^{23}$ Additionally, porphyrins and metalloporphyrins have demonstrated good features as analytical sensors because they can provoke electrocatalysis, increasing the sensitivity and selectivity of the electrode..$^{24-27}$

In this context, the present work reports the development of an efficient and stable sensor for oncocalyxone A (1) determination, based on a glassy carbon electrode modification with a bilayer produced by drop-casting of iron(II) tetrasulfonated phthalocyanine (negatively charged) and iron(III) tetra-( $N$-methyl-4-pyridyl)-porphyrin (positively charged), where presumably a strong interaction is established by ion-pair formation between the ammonium group of the porphyrin and the sulfonic $\left(-\mathrm{SO}_{3}^{-}\right)$group of the phthalocyanine.

\section{Experimental}

\section{Chemical and solutions}

All used chemicals were analytical grade. Iron(II) tetrasulfonated phthalocyanine (FeTSPc) was synthesized and purified according to the procedure of Weber and Busch. ${ }^{28}$ Iron(III) tetra-( $N$-methyl-4-pyridyl)-porphyrin ( $\left.\mathrm{FeT}_{4} \mathrm{MPyP}\right)$ was acquired from Porphyrin Products Inc. (UT, USA). Oncocalyxone A (1) (Figure 1), which data is presented, was isolated from wood parts of Auxemma oncocalyx collected in June 2005, at Pentecoste County, State of Ceará, Brazil. The plant was identified by Professor Edson P. Nunes, and a voucher specimen (No. 18459) is deposited at the Herbarium Prisco Bezerra (EAC) of the Departamento de Biologia, Universidade Federal do Ceará, Fortaleza, Ceará, Brazil. The extract preparation, methods of isolation and chemical characterization were previously described by Pessoa et al. ${ }^{6-8}$

rel-8 $\alpha$-Hydroxy-5-hydroxymethyl-2-methoxy-8a $\beta$ methyl-7,8,8a,9-tetrahydro-1,4-anthracenedione (1), ${ }^{7} \mathrm{mp}$ 209-211 ${ }^{\circ} \mathrm{C}$; IR $v_{\max } / \mathrm{cm}^{-1}(\mathrm{KBr}): 3446,3039,1657,1626$, 1602, 1543, 1263, 1233, 1086; EIMS m/z $302[\mathrm{M}]^{+}, 284$, $255,241,225,211,169,128,115,102,69 ;{ }^{1} \mathrm{H}$ NMR (200 MHz, DMSO- $\left.d_{6}\right) \delta 6.00$ (s, H3), 6.02 (d, J3.9 Hz, H6), 2.52 (br d, $J 17.2 \mathrm{~Hz}, \mathrm{H} 7 \mathrm{eq}$ ), 2.60 (dd, $J 17.2,3.9 \mathrm{~Hz}, \mathrm{H} 7 \mathrm{ax}$ ), 3.55 (br s, H8), 2.90 (d, $J 18.4$ Hz, H9ax), 2.34 (d, $J 18.4$ Hz, H9eq), 6.48 (s, H10), 4.16 (br s, 2H11), 0.73 (s, 3H12), 3.73 (s, OMe), 4.93 (d, 4.5, OH8), 4.88 (t, 5.2, OH11).

${ }^{13} \mathrm{C}$ NMR (50.3 MHz, DMSO- $\left.d_{6}\right) \delta 180.9$ (C1), 159.5 (C2), 106.0 (C3), 184.9 (C4), 134.2 (C4a), 146.4 (C5), 128.1 (C6), 31.6 (C7), 69.7 (C8), 38.9 (C8a), 28.8 (C9), 
132.7 (C9a), 111.5 (C10), 135.1 (C10a), 61.3 (C11), 20.9

(C12), 56.4 (OMe).

Monobasic sodium phosphate $\left(\mathrm{NaH}_{2} \mathrm{PO}_{4}\right)$, dibasic sodium phosphate $\left(\mathrm{Na}_{2} \mathrm{HPO}_{4}\right)$, citric acid $\left(\mathrm{C}_{6} \mathrm{H}_{8} \mathrm{O}_{7}\right)$, acetonitrile $\left(\mathrm{CH}_{3} \mathrm{CN}\right)$, sodium hydroxide $(\mathrm{NaOH})$, hydrochloric acid $(\mathrm{HCl})$ were acquired from Merck, Rio de Janeiro, Brazil, PIPES [piperazine- $N, N$ '-bis(2ethanesulfonic acid)] and HEPES [ $N$-(2-hydroxyethyl) piperazine- $N$-(2-ethanesulfonic acid)] were acquired from Sigma, St. Louis, USA. Phosphate, McIlvaine, HEPES and PIPES buffers and solutions of $\mathrm{FeT}_{4} \mathrm{MPyP}$ and FeTSPc were prepared with water purified in a Milli-Q Millipore system and the actual $\mathrm{pH}$ values of the buffer solutions were determined with a Corning pH/Ion Analyzer 350 model.

\section{Voltammetric measurements}

The voltammetric measurements were carried out in an Autolab PGSTAT-30 potentiostat from Echo Chemie (Utrecht, The Netherlands) coupled to a PC microcomputer with GPES 4.9 software. An electrochemical cell containing $5.0 \mathrm{~mL}$ of phosphate buffer solution with a saturated calomel electrode (SCE) as reference, a Pt wire as auxiliary and a modified GC as working electrode were used for all measurements. Oxygen was removed by bubbling nitrogen through the solution, during 5 to $10 \mathrm{~min}$. The optimized parameters in Square Wave Voltammetry (SWV) were set up using a step potential $\left(\Delta E_{\mathrm{s}}\right) 0.002 \mathrm{~V}$, pulse amplitude $\left(\Delta E_{\mathrm{sW}}\right) 0.05 \mathrm{~V}$ and frequence $(f) 100 \mathrm{~Hz}$.

\section{Construction of the sensor}

The glassy carbon electrode, with geometrical area of $0.071 \mathrm{~cm}^{2}$ was acquired from BAS-USA, and used for all measurements. Prior to the modification, the electrode surface was treated according to the procedure described by Zhu and Nan-Qiang. ${ }^{29}$ After cleaning the electrode, an electrostatically formed layer was prepared on the electrode surface by drop-casting, transferring $15 \mu \mathrm{L}$ of a FeTSPc solution, in the concentrations $0.01,0.05,0.1,0.15$ and $0.19 \mathrm{mmol} \mathrm{L}^{-1}$ and let to dry at $80^{\circ} \mathrm{C}$ during $10 \mathrm{~min}$. After $10 \mathrm{~min}, 15 \mu \mathrm{L}$ of the $\mathrm{FeT}_{4} \mathrm{MPyP}$ solution, in the concentrations $0.01,0.05,0.1,0.15$ and $0.19 \mathrm{mmol} \mathrm{L}^{-1}$, respectively, were added to the electrode surface and also let to dry at $80{ }^{\circ} \mathrm{C}$ during $10 \mathrm{~min}$. The bilayers were prepared by repeating the procedure described above. Presumably the interaction between FeTSPc and $\mathrm{FeT}_{4}$ MPyP complexes occurs by ion-pairing between the amino group $\left(-\mathrm{C}_{6} \mathrm{H}_{8} \mathrm{~N}^{+}\right)$of the iron porphyrin and the anionic $-\mathrm{SO}_{3}^{-}$of the tetrasulfonated phthalocyanine. For the sensor optimization, a bilayer of FeTSPc $+\mathrm{FeT}_{4} \mathrm{MPyP}$ complexes was prepared.

\section{Analytical curve}

After optimizing experimental parameters for the proposed sensor, the analytical curve was built by addition of aliquots of $\mathbf{1}$ (stock solution of $1.0 \mu \mathrm{mol} \mathrm{L}^{-1}$ in acetonitrile/water, 1:1 v/v, kept under nitrogen and dark) into measurement cell containing phosphate buffer solution $\left(0.05 \mathrm{~mol} \mathrm{~L}^{-1}\right)$ at $\mathrm{pH}$ 7.0. The technique employed was square wave voltammetry (SWV), ${ }^{30}$ and the SWV characteristic parameters were: step potential $\left(\Delta E_{\mathrm{s}}\right) 0.002 \mathrm{~V}$, frequency $(f)$ $100 \mathrm{~Hz}$ and pulse amplitude $\left(\Delta E_{\mathrm{SW}}\right) 0.050 \mathrm{~V}$.

\section{Results and Discussion}

Electrocatalytic reduction of $\mathbf{1}$ on the modified electrode

Figure 2 shows the cyclic voltammograms for the unmodified GC electrode in absence (a) and presence (b) of $1\left(5 \times 10^{-6} \mathrm{~mol} \mathrm{~L}^{-1}\right)$ and the voltammograms for the modified GC electrode with a layer of FeTSPc alone in presence of $5 \times 10^{-6} \mathrm{~mol} \mathrm{~L}^{-1} \mathbf{1}$ (c) and a layer of $\mathrm{FeT}_{4} \mathrm{MPyP}$ (e) in presence of $1\left(5 \times 10^{-6} \mathrm{~mol} \mathrm{~L}^{-1}\right)$. For comparison, this figure also presents the cyclic voltammograms for the modified GC electrode with a bilayer of $\mathrm{FeTSP} / \mathrm{FeT}_{4} \mathrm{MPyP}$ in the absence (d) and presence ( $\mathrm{f}$ ) of $\mathbf{1}\left(5 \times 10^{-6} \mathrm{~mol} \mathrm{~L}^{-1}\right)$ in $0.1 \mathrm{~mol} \mathrm{~L}^{-1}$ phosphate buffer solution ( $\mathrm{pH}$ 7.0). In presence of 1 (Figure 2b), a typical quinone reduction behavior is

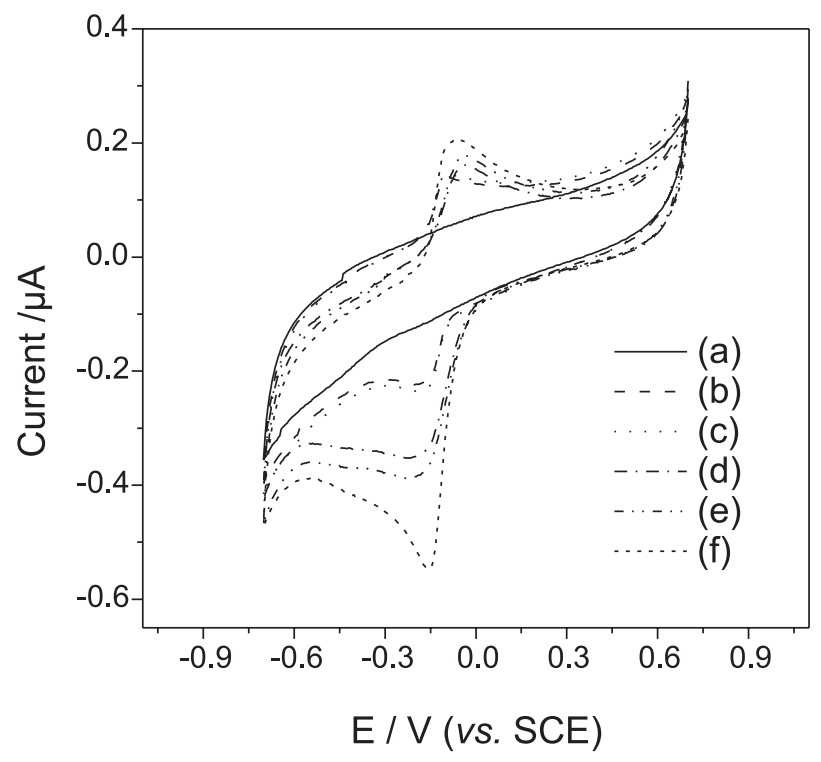

Figure 2. Cyclic voltammograms for the unmodified GC electrode in absence (a) and presence (b) of $\mathbf{1}\left(5 \times 10^{-6} \mathrm{~mol} \mathrm{~L}^{-1}\right)$ and the voltammograms for the modified GC electrode with a layer of FeTSPc alone in presence of $\mathbf{1}\left(5 \times 10^{-6} \mathrm{~mol} \mathrm{~L}^{-1}\right)(\mathrm{c})$ and a layer of $\mathrm{FeT}_{4} \mathrm{MPyP}$ in presence of $\mathbf{1}$ $\left(5 \times 10^{-6} \mathrm{~mol} \mathrm{~L}^{-1}\right)$ (e) For comparison, the cyclic voltammograms for the modified GC electrode with a bilayer of FeTSPc/FeT $\mathrm{MPyP}_{4}$ in the absence (d) and presence (f) of $1\left(5 \times 10^{-6} \mathrm{~mol} \mathrm{~L}^{-1}\right)$ in $0.1 \mathrm{~mol} \mathrm{l}^{-1}$ phosphate buffer solution ( $\mathrm{pH} 7.0)$. Scan rate: $0.025 \mathrm{~V} \mathrm{~s}^{-1}$. 
shown, represented by a reversible pair of waves, with uptake of $2 \mathrm{e}^{-}$and $2 \mathrm{H}^{+}$, generating the hydroquinone. .,31-32 $^{2}$

As can be seen, the best response for $\mathbf{1}$ was obtained with the FeTSPc/FeT 4 MPyP modified GC electrode (Figure 2f). On this modified electrode, an anodic shift of the reduction peak potential of $c a .30 \mathrm{mV}$ and a much higher peak current for $\mathbf{1}$ than those obtained on the bare GC electrode were observed (Figure 2b compared to 2f). Additionally, on this electrode, the peak current for the reduction of $\mathbf{1}$ was also higher than that ones showed on the electrode modified with only $\mathrm{FeT}_{4} \mathrm{MPyP}$ or FeTSPc (Figures $2 \mathrm{c}$ or 2e, respectively, compared to $2 \mathrm{f}$ ).

The reduction of $\mathbf{1}$ on $\mathrm{FeT}_{4} \mathrm{MPyP}$ modified electrode (Figure 2e) occurred next to the reduction current of the FeTSPc/FeT ${ }_{4}$ MPyP modified GC electrode (Figure 2d). When only $\mathrm{FeT}_{4} \mathrm{MPyP}$ was used, a poor response was observed (Figure 2e). This suggests that the $\mathrm{FeT}_{4} \mathrm{MPyP}$ complex effectively increases the reduction rate of $\mathbf{1}$, while the FeTSPc layer must be improving the assembly of the active sites of $\mathrm{FeT}_{4}$ MPyP resulting in a better catalyst for $\mathbf{1}$.

The interaction of the FeTSPc/FeT 4 MPyP complexes and the increase in the peak current of $\mathbf{1}$ (Figure 2f), when compared to the bare electrode (Figure 2b) can be associated to the redox reactions of the immobilized $\left[\mathrm{Fe}(\mathrm{III}) \mathrm{T}_{4} \mathrm{MPyP}\right]^{5+}$ and $[\mathrm{Fe}(\mathrm{II}) \mathrm{TSP}]^{4-}$ giving $\left[\mathrm{Fe}(\mathrm{II}) \mathrm{T}_{4} \mathrm{MPyP}\right]^{4+}$ and $[\mathrm{Fe}(\mathrm{III})$ $\mathrm{TSPc}^{3-}$ species. $\left[\mathrm{Fe}(\mathrm{II}) \mathrm{T}_{4} \mathrm{MPyP}\right]^{4+}$ is oxidized back, reducing the quinone (1), originating the catalytic cycle (equations 1 and 2). $[\mathrm{Fe}(\mathrm{IIII}) \mathrm{TSP}]^{3-}$ species is electrochemically reduced to $[\mathrm{Fe}(\mathrm{II}) \mathrm{TSP} c]^{4}$ leading to a cycle. Therefore, the high activity of the modified GC electrode for the reduction of $\mathbf{1}$ in aqueous solutions can be associated with the low charge transfer resistance of the FeTSPc/FeT $\mathrm{FPyP}_{4}$ bilayer as well the presence of $\mathrm{FeT}_{4} \mathrm{MPyP}$ as an electrocatalyst. The combination of these points proportionates a powerful catalytic property for the reduction of $\mathbf{1}$. This effect results from the changes in the chemical environment around the active sites, induced by the contrasting molecular packing interactions with $\mathrm{FeT}_{4} \mathrm{MPyP}$. The catalytic properties and the use of phthalocyanines and porphyrin bilayers have been described ${ }^{33}$ and in the present case can be written as follow:

$$
\begin{gathered}
{\left[\mathrm{Fe}(\mathrm{III}) \mathrm{T}_{4} \mathrm{MPyP}^{5+}+[\mathrm{Fe}(\mathrm{II}) \mathrm{TSPc}]^{4-} \leftrightarrows\right.} \\
{\left[\mathrm{Fe}(\mathrm{II}) \mathrm{T}_{4} \mathrm{MPyP}\right]^{4+}+[\mathrm{Fe}(\mathrm{III}) \mathrm{TSPc}]^{3-}} \\
2\left[\mathrm{Fe}(\mathrm{II}) \mathrm{T}_{4} \mathrm{MPyP}^{4+}+\text { oncocalyxone }_{\text {oxi }} \leftrightarrows\right. \\
2\left[\mathrm{Fe}(\mathrm{III}) \mathrm{T}_{4} \mathrm{MPyP}^{5+}+\left[\text { oncocalyxone }_{\text {red }}\right]^{2-}\right.
\end{gathered}
$$

Influence of the concentration of FeTSPc and $\mathrm{FeT}_{4} \mathrm{MPyP}$ in the sensor response

The concentrations of FeTSPc and $\mathrm{FeT}_{4}$ MPyP are a control factor and influence the electrochemical behavior in larger extent. Thus, the dependence of the complexes concentration on the electrode response for 1 was investigated by preparing a bilayer with different concentrations of FeTSPc as well as for $\mathrm{FeT}_{4}$ MPyP: 0.01, $0.05,0.1,0.15$ and $0.19 \mathrm{mmol} \mathrm{L}^{-1}$. The results showed in Table 1 indicate that the best response was obtained using $0.1 \mathrm{mmol} \mathrm{L}^{-1}$ of both complexes.

Table 1. Influence of the FeTSPc and $\mathrm{FeT}_{4} \mathrm{MPyP}$ concentrations, used in the film preparation, on the peak current obtained with the sensor for $0.3 \mathrm{~mol} \mathrm{~L}^{-1} \mathbf{1}$ in $0.1 \mathrm{~mol} \mathrm{~L}^{-1}$ phosphate buffer solution at $\mathrm{pH} 7.0$

\begin{tabular}{ll}
\hline$[\mathrm{FeTSPc}]:\left[\mathrm{FeT}_{4} \mathrm{MPyP}\right]$ & $-I_{p} / \mu \mathrm{A}$ \\
$\left(\times 10^{-4} \mathrm{~mol} \mathrm{~L}^{-1}\right)$ & 1.40 \\
\hline $0.1: 1.9$ & 1.43 \\
$0.5: 1.5$ & 2.29 \\
$1.0: 1.0$ & 1.23 \\
$1.5: 0.5$ & 0.75 \\
$1.9: 0.1$ & \\
\hline
\end{tabular}

Lower current values were obtained when the amount of FeTSPc was higher than $\mathrm{FeT}_{4} \mathrm{MPyP}$, and vice-versa: when the amount of $\mathrm{FeT}_{4} \mathrm{MPyP}$ increases, a similar trend was observed. This trend suggests that the better ratio for FeTSPc/FeT ${ }_{4}$ MPyP assembly is 1, ideal for the kinetic of electron transfer. In this condition, high current values were obtained. The concentration of $0.1 \mathrm{mmol} \mathrm{L}^{-1}$ for each constituent of the complex FeTSPc/FeT ${ }_{4}$ MPyP was chosen for further experiments.

\section{Influence of $p H$, buffer solution and buffer concentration}

The influence of the solution $\mathrm{pH}$ in the electrochemical reduction response of 1 using $0.1 \mathrm{~mol} \mathrm{~L}^{-1}$ phosphate buffer at pH 6.0, 6.4 , 7.0, 7.4 and 8.0 was studied (Figure 3). The peak current increased with $\mathrm{pH}$ in the range from 6.0 up to 7.0. The highest peak current was obtained in $\mathrm{pH}$ 7.0. A decrease in the current is observed when the solution $\mathrm{pH}$ is higher than 7.0. Thus, the optimum $\mathrm{pH}$ for further studies was set in 7.0. In addition, this study showed that the oncocalyxone reduction peak potential undergoes, as expected, a slight cathodic displacement when the $\mathrm{pH}$ solution increases. The influence of the buffer solution on the sensor response was tested for four different buffer solutions (HEPES, Mcllvaine, PIPES and phosphate) with concentrations of $0.1 \mathrm{~mol} \mathrm{~L}^{-1}$. The best responses were obtained in phosphate buffer (Figure 4) that was chosen as the buffer solution.

Figure 5 shows the influence of different concentrations of phosphate buffer $(0.025,0.050,0.10,0.15$ and $0.20 \mathrm{~mol} \mathrm{~L}^{-1}$ ) for the measurement of $\mathbf{1}$. The best response was obtained for the concentrations of 0.05 and $0.1 \mathrm{~mol} \mathrm{~L}^{-1}$; 


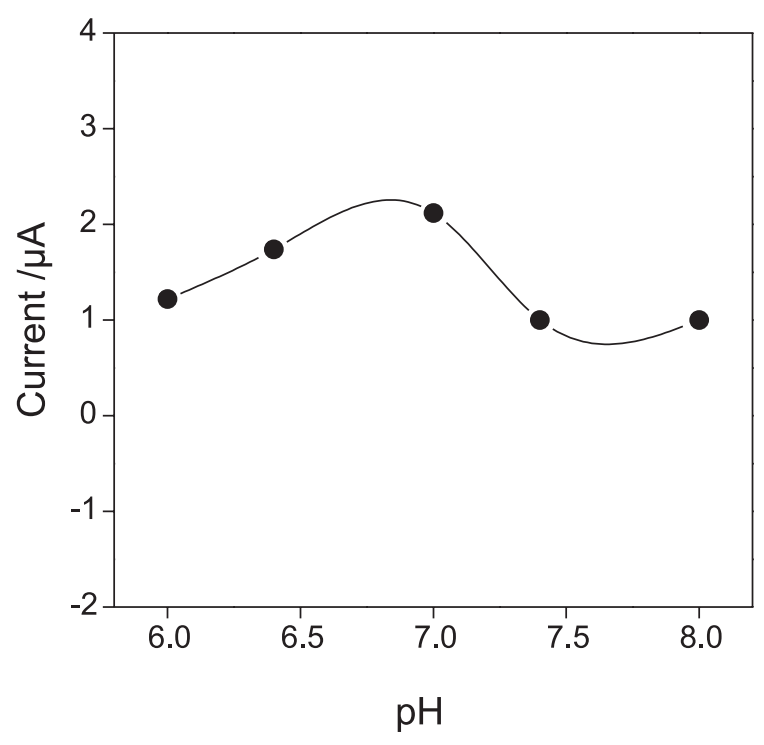

Figure 3. Influence of $\mathrm{pH}$ on the sensor response obtained by SWV in $0.3 \mu \mathrm{mol} \mathrm{L}-1$. Measurements carried out in $0.1 \mathrm{~mol} \mathrm{~L}^{-1}$ in phosphate buffer. $\Delta \mathrm{E}_{\mathrm{s}}=0.002 \mathrm{~V}, f=80 \mathrm{~Hz}$ and $\mathrm{a}=0.03 \mathrm{~V}$.

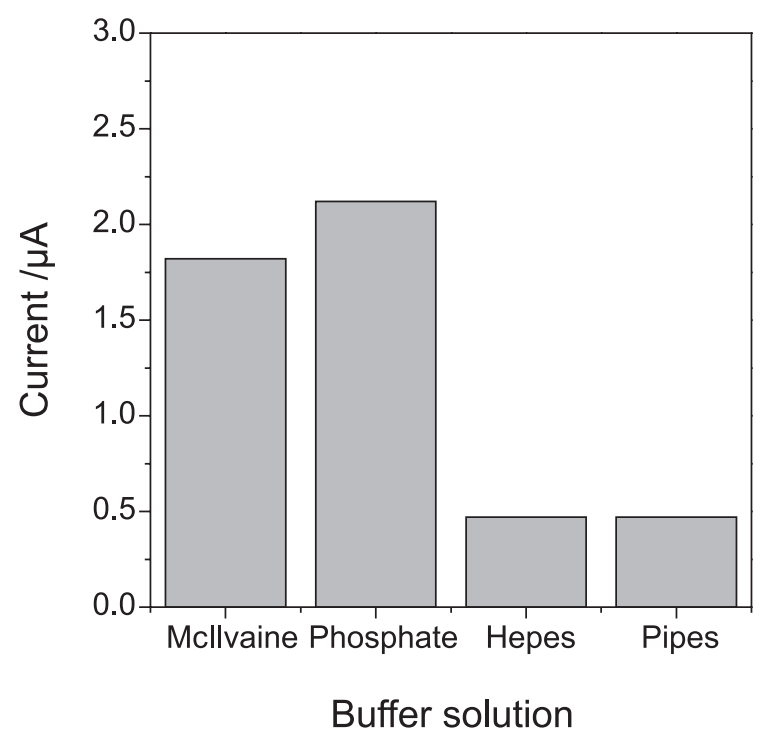

Figure 4. Influence of the buffer solution on the sensor response obtained by SWV in $0.3 \mu \mathrm{mol} \mathrm{L}^{-1} \mathbf{1}$. Measurements carried out in $0.1 \mathrm{~mol} \mathrm{~L}^{-1}$ buffer solution, $\mathrm{pH}$ 7.0. $\Delta \mathrm{E}_{\mathrm{s}}=0.002 \mathrm{~V}, f=80 \mathrm{~Hz}$ and $\mathrm{a}=0.03 \mathrm{~V}$.

outside this range, a current decrease has been observed. Based on this, the concentration of $0.05 \mathrm{~mol} \mathrm{~L}^{-1}$ was chosen for further experiments.

\section{Influence of the frequency $(f)$ and potential amplitude (a)}

The effects of the frequency and potential amplitude on the square wave voltammetry (SWV) response of the FeTSPc/FeT 4 MPyP modified GC electrode, in phosphate buffer solution were verified. The peak current values

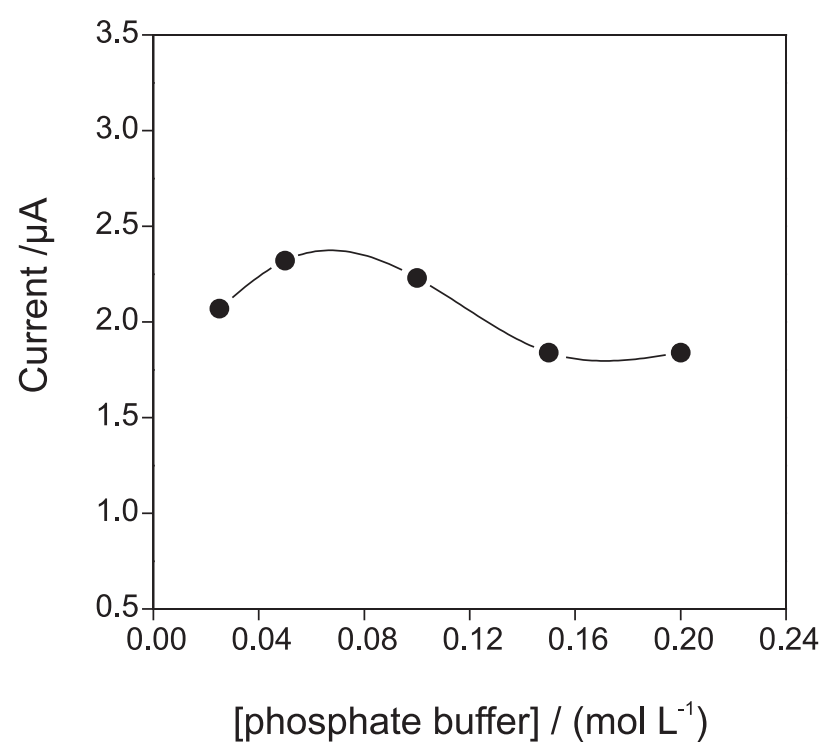

Figure 5. Influence of the phosphate buffer concentration, $\mathrm{pH} 7.0$, on the peak current obtained by SWV with the sensor for $0.3 \mu \mathrm{mol} \mathrm{L}^{-1} \mathbf{1}$. $\Delta \mathrm{E}_{\mathrm{s}}=0.002 \mathrm{~V}, f=80 \mathrm{~Hz}$ and $\mathrm{a}=0.03 \mathrm{~V}$.

presented a linear increase with the frequency variation from 20 to $140 \mathrm{~Hz}$ with $\Delta \mathrm{E}_{\mathrm{s}}=0.002 \mathrm{~V}$. However, when the frequency is $>100 \mathrm{~Hz}$, the current peak value remained almost constant, accompanied by distortion of the peaks. As it sets the best voltammetric profile with higher sensitivity, the frequency of $100 \mathrm{~Hz}$ was chosen and subsequently used throughout the present study. The current values of peak were also found to vary with pulse amplitude of 0.010-0.080 V applied on SWV at a frequency of $100 \mathrm{~Hz}$ for the modified electrode and $\Delta \mathrm{E}_{\mathrm{s}}=0.002 \mathrm{~V}$. The use of the pulse amplitude $>0.050 \mathrm{~V}$ led to the peak current values almost constant and an increase in the background current. In this sense, the best sensitivity was obtained with $0.050 \mathrm{~V}$ and therefore, this value was chosen for further studies.

\section{Analytical characterization}

In order to obtain an analytical curve for $\mathbf{1}$, with the developed sensor, under optimized conditions (phosphate buffer, $0.05 \mathrm{~mol} \mathrm{~L}^{-1}, \mathrm{pH}$ 7.0), experiments were carried out adding aliquots of $\mathbf{1}$ from a stock solution (Figure 6), kept in dark and protected from oxygen. Under optimized conditions the proposed sensor showed a linear response ranging from $5.0 \mathrm{nmol} \mathrm{L}-1$ up to $1.2 \mu \mathrm{mol} \mathrm{L}^{-1}$, which can be expressed according to equation 3 :

$I_{p}(\mu \mathrm{A})=0.23( \pm 0.90)+8.11( \pm 0.17)[1]\left(\mu \mathrm{mol} \mathrm{L}^{-1}\right)$

with a correlation coefficient of 0.996 (for $n=8$ ) and with good sensitivity and limit of detection which can be attributed to the efficiency of the electron transfer 

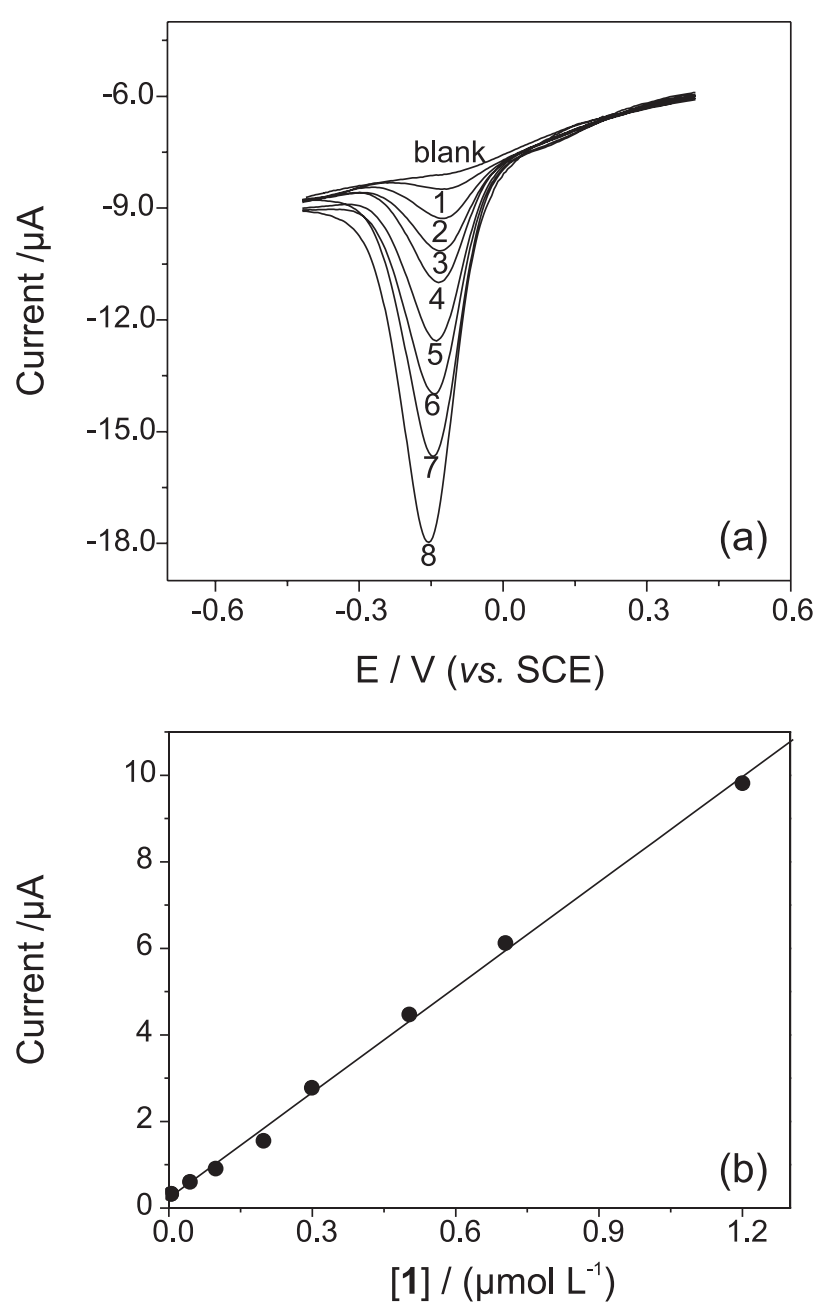

Figure 6. SWV for the electro-reduction of $\mathbf{1}$ in phosphate buffer (0.05 mol L-1 at $\mathrm{pH} 7.0)$ obtained in the optimized conditions for concentration range from (1) 0.005 , (2) 0.044 , (3) 0.098 , (4) 0.198 , (5) 0.299 , (6) 0.503 , (7) 0.704 , and (8) $1.2 \mu \mathrm{mol} \mathrm{L}^{-1}$ (a). Analytical curve (b). $\Delta \mathrm{E}_{\mathrm{s}}=0.002 \mathrm{~V}, f=100 \mathrm{~Hz}$ and $\mathrm{a}=0.05 \mathrm{~V}$.

between the FeTSPc/FeT $\mathrm{FPyP}_{4}$ film and $\mathbf{1}$. Additionally, the proposed sensor presented a relatively wide linear response range, which can be related with the high affinity between the catalyst and the analyte. The limit of detection of $1.5 \mathrm{nmol} \mathrm{L}^{-1}$ was determined using a $3 \sigma /$ slope ratio and limit of quantification was $5.0 \mathrm{nmol} \mathrm{L^{-1 }}$ using $10 \sigma /$ slope, where $\sigma$ is the standard deviation of the mean value for 10 voltammograms of the blank, determined according to IUPAC recommendations. ${ }^{34}$

\section{Conclusions}

This work demonstrated that glassy carbon electrode modified by alternating FeTSPc and $\mathrm{FeT}_{4}$ MPyP, layer by layer, is a feasible alternative for the analytical determination of 1. Optimization of the experimental conditions for square wave voltammetry furnished a low limit of detection and high sensitivity for oncocalyxone. In this sense, this work demonstrated that the glassy carbon electrode modified with $\mathrm{FeTSPc} / \mathrm{FeT}_{4} \mathrm{MPyP}$ is a sensitive, robust and stable sensor showing great potential for oncocalyxone determination and additionally to be employed as an electrochemical detector in HPLC.

\section{Acknowledgments}

The authors thank CAPES, CNPq, FAPESP, FAPEAL, CNPq/PADCT, CNPq/MS/Neoplasias, CNPq/Instituto do Milênio-IMINOFAR, CTPETRO and BNB for financial support and fellowships.

\section{References}

1. O'Brien, P. J.; Chem. Biol. Interact. 1991, 80, 1.

2. Aguilar-Martinez, M.; Macías-Ruvalcaba, N. A.; BautistaMartínez, J. A.; Gómez, M.; González, F. J.; González, I.; Curr. Org. Chem. 2004, 8, 1721.

3. Bolton, J. L.; Trush, M.; Penning, T.; Dryhurst, G.; Monks, T. J.; Chem. Res. Toxicol. 2000, 13, 135.

4. Monks, T. J.; Jones, D. C.; Curr. Drug Metabolism 2002, 3, 425.

5. Hillard, E. A.; de Abreu, F. C.; Ferreira, D. C. M.; Jaouen, G.; Goulart, M. O. F.; Amatore, C.; Chem. Commun, submitted.

6. Pessoa, O. D. L.; Lemos, T. L. G.; Silveira, E. R.; Braz-Filho, R.; Nat. Prod. Lett. 1993, 2,145.

7. Pessoa, C.; Lemos, T. L. G.; Pessoa, O. D. L.; Moraes, M. O.; Vasconcellos, D.; Costa-Lotufo, L. V.; Leyva, A.; Arkivoc 2004, VI, 89.

8. Pessoa, O. D. L.; Lemos, T. L. G.; Carvalho, M. G.; Braz-Filho, R.; Phytochemistry 1995, 6, 1777.

9. Marques, W. B.; Pessoa, O. D. L.; Lemos, T. L. G.; Braz-Filho, R.; Rev. Latinoamer. Quím. 2000, 28, 111.

10. Costa-Lotufo, L. V.; Ferreira, M. A. D.; Lemos, T. L. G.; Pessoa, O. D. L.; Viana, G. S. B.; Cunha, G. M. A.; Braz. J. Med. Biol. Res. 2002, 35, 927.

11. Ferreira, M. A. D.; Nunes, O. D. R. H.; Leal, L. K. A. M.; Pessoa, O. D. L.; Lemos, T. L. G.; Viana, G. S. B.; Biol. Pharm. Bull. 2003, 26, 595.

12. Ferreira, M. A. D.; Nunes, O. D. R. H.; Fontenele, J. B.; Pessoa, O. D. L.; Lemos, T. G. L.; Viana, G. S. B.; Phytomedicine 2004, 11,315 .

13. Hamburger, M.; Hostettmann, K.; Phytochemistry 1991, 30, 3864.

14. Cardellina, J. H.; J. Nat. Prod. 2002, 65, 1073.

15. Lodhi, A. H.; Santana, A. E. G.; Charlwod, B. V.; Phytochemistry Analysis 1994, 5, 261.

16. Ruckert, U.; Likussar, W.; Michelitsch, A.; Phytochem. Anal. 2007, 18, 204. 
17. Luz, R. C. S.; Damos, F. S.; Oliveira, A. B.; Beck, J.; Kubota, L. T.; Talanta 2004, 64, 935.

18. Luz, R. C. S.; Damos, F. S.; Oliveira, A. B.; Beck, J.; Kubota, L. T.; Electrochim. Acta 2005, 50, 2675.

19. Damos, F. S.; Sotomayor, M. D. T.; Kubota, L. T.; Tanaka, S. M. C. N.; Tanaka, A. A.; Analyst 2003,128, 255.

20. Revenga-Parra, M.; Lorenzo, E.; Pariente, F.; Sens. Actuators B 2005, 107, 678 .

21. Yang, S.; Li, Y.; Jiang, X.; Chen, Z.; Lin, X.; Sens. Actuators B: Chem. 2006, 114, 774.

22. Huang, H. X.; Qian, D. J.; Nakamura, N.; Nakamura, C.; Wakayama, T.; Miyake, J.; Electrochim. Acta 2004, 49, 1491.

23. Sun, C.; Zhao, J.; Xu, H.; Sun, Y.; Zhang, X.; Shen, J.; Talanta 1998, 46, 15.

24. Manriquez, J.; Bravo, J. L.; Granados, S. G.; Succar, S. S.; Bied Charreton, C.; Ordaz, A. A.; Bedioui, F.; Anal. Chim. Acta 1999, $378,159$.

25. Mímica, D.; Zagal, J. H.; Bedioui, F.; Electrochem. Commun. 2001, 3, 435 .
26. Ozoemena, K. I.; Nyokong, T.; Talanta 2005, 67, 162.

27. Ozoemena, K. I.; Zhao, Z.; Nyokong, T.; Electrochem. Commun. 2005, 7679.

28. Weber, J. H.; Busch, D. H.; Inorg. Chem. 1965, 4, 469.

29. Zhu, Z.; Nan-Qiang, L.; Electroanalysis 1998, 10, 643.

30. Souza, D.; Machado, S. A. S.; Avaca, L. A.; Quim. Nova 2003, $26,1$.

31. Jacq, J.; Electrochim. Acta 1967, 12, 1345.

32. De Abreu, F. C.; Goulart, M. O. F.; Oliveira-Brett A. M.; Electroanalysis 2002, 14, 29.

33. Santos, W. J. R.; Sousa, A. L.; Luz, R. C. S.; Damos, F. S.; Kubota, L. T.; Tanaka, A. A.; Tanaka, S. M. C. N.; Talanta 2006, 70, 588.

34. Analytical Methods Commitee, Analyst 1987, 112, 199.

Received: September 1, 2007

Web Release Date: April 2, 2008

FAPESP helped in meeting the publication costs of this article. 